\title{
Uses of the Discourse Marker Wallahi in Jordanian Spoken Arabic: A Pragma- Discourse Perspective
}

\author{
Asim Al-Khawaldeh \\ Department of Modern Languages \\ Al-alBayt University \\ Jordan
}

\begin{abstract}
The present study aims at examining and describing the uses of the discourse marker "wallahi" in Jordanian spoken Arabic. To meet the purpose of the study, a corpus of 8 hours of spoken discourse has been collected, including face-to -face as well as cell phones conversations. The study employs 26 participants, varied in gender, age, education, and job. Due to the fact that it is massively frequent in Jordanian Arabic, this DM has been chosen foran in-depth functional study. The nature of the study is exploratory and functional, attempting to provide a corpus -based description and analysis. As a qualitative research, an eclectic analytical method is employed as a theoretical framework to account for the functions of the discourse marker wallahi. In addition, it relies on utilizing direct observation technique for analyzing the DM wallahi in the corpus under investigation. The results of the study show that the DM wallahi is multifunctional, serving ten functions in the present corpus: to introduce an acceptance, an apology, a threat, and a compliment, and to serve as a request softener, a marker of elaboration, a continuer, a marker of confirmation, a marker of complying with a request, and a filler marker.
\end{abstract}

Keywords: wallahi, discourse marker, pragmatic functions, spoken Arabic, corpus.

\section{Introduction}

As an essential means of everyday communication in human society, people not only use language to convey information content but also to express their opinions, attitudes, and feelings. Among its vast multifarious functions across contexts in social interaction are arguing, convincing, ordering, requesting, promising, and complaining. Language provides numerous linguistic devices to achieve these different functions-that is, different suitable forms of structures as well as expressions are required by different contexts. Therefore, interlocutors adjust their own language according to whom they are addressing, especially, for the purpose of establishing and keeping social relationships. In different situations, the same expression or wordmay have different interpretations. Putting it differently, meanings are highly influenced by their actual social situation or context. Discourse analysis and Pragmatics are mainly concerned with the analysis of language in use, focusing on describing linguistic forms as well as their purposes and functions (Brown \&Yule, 1983). More specifically, as a major contribution to linguistic research, Pragmatics has directed attention to actual use of language and made it necessary to relate linguistic investigation to aspects of context (levinson,1983), where the term context is held to encompass the spatial and temporal aspects of the speech event and the identities, knowledge, beliefs, intentions of speakers and hearers. It also focuses on the speaker's intended meaning rather than the linguistic propositional meaning (literal meaning). Yule $(2008$, p. 3) points out that "Pragmatics is concerned with the study of meaning as communicated by a speaker (or writer) and interpreted by a listener (or reader)". One of the remarkable linguistic phenomena frequently used in language and has recently drawn the attention of linguists and scholars from different perspectives and approaches is discourse markers. Discourse markers (DMs henceforward) have recently received considerable attention in linguistic studies. They have been treated across languages from different approaches, perspectives, and frameworks (Shciffrin 1987;Fraser 1999; Schourup 1999;Blakemore 2001). However, no consensus has been reached on the definition, features, and terminology, classification among researchers (Schourup, 1999). Multiplicity of terms have been suggested to label this class, for instance, Discourse Markers (Schiffrin, 1987), Pragmatic Markers (Brinton, 1996), Discourse Particles (Abraham, 1991), Discourse Connectives (Blakemore, 1989), and Phrase Cues (Knott, 1993). This wide range of labels, according to Schourup (1999), results into making these functional expressions problematic to characterize. However, the term Discourse Marker is held to be the most popular one among the other terms. 
In the literature, DMs are given different features, varying from the most common to the least and from criterion to non-criterion. DMs do not contribute to the truth-condition or propositional content of their host utterance. This claim implies that DMs have pragmatic meaning rather than semantic one. For the distinction between semantic and pragmatic meaning, Blakemore (2001) uses the term conceptual and procedural meaning, respectively. She argues that linguistic expressions (including DMs) encode one of them as the focus should be placed on the procedural side since it works to control the inferential processing of a given utterance (Blakemore, 2002). Like Blakemore, Fraser (1999) highlights that DMs contribute only to the procedural meaning, providing instructions to the listener on how the utterance in question to be interpreted. This notion is supported by Aijmer (2002) that pragmatic functions DMs perform in context overshadow their semantic/literal meaning. Due to this fact that DMs have nothing to do with the propositional content or truth conditions of their host utterance, the study of DMs has primarily been given much more attention and focus in the field of Pragmatics and Discourse analysis than other linguistic fields (Moore, 2007).

Syntactically, they are independent, detachable or loosely attached to a sentence (Shciffrin, 1987, Brinton, 1996). Therefore, they are optional and their deletion does not render their host sentence ungrammatical though they are pragmatically required for the process of communicative interpretation. They are immensely context-specific, whose functions can be properly interpreted by looking at the speaker's intentions and attitudes or the situation in which they are given (Aijmer, 2002). In other words, the nature of their main function is pragmatic, guiding the hearer's attention to the intended relation between the host utterance and the immediate discourse context (Redeker,1990).It is generally agreed that DMs are multifunctional and frequently used in discourse (particularly spoken discourse).It is argued that DMs have "one core meaning even though they can express specific meaning depending on the context of the utterance" (Nasir, 2017,p. 14). Therefore, DMs are observed to operate on both the textual level (organization of text) and interpersonal level (the relationships of interlocutors). With respect to position, DMs are syntactically flexible to appear in initial, medial, and final position of their host discourse segment. Yet, they are commonly observed to occur initially. Lexically, DMs are heterogeneous i.e.they do not belong to a particular grammatical class of words and are derived from different grammatical class such as nouns, verbs, conjunctions, and prepositional phrases. DMs are thought to play a key role in connecting discourse units through marking the relations among them.

Based on Schiffrin (1987), DMs can be defined as linguistic units whose primary function is not to contribute to the propositional meaning of an utterance, but to indicate to the hearer "how they should understand what follows or what came before with respect to each other and to the discourse as a whole" (Lee-Goldman, 2011, p. 2628). Within his grammatical-pragmatic approach, Fraser (1999) defines DMs as linguistics expressions drawn from different syntactic classes, used to indicate relations between discourse units, and they have procedural rather than conceptual meaning whose specific interpretation is identified by context. According to Aijmer (2002, p. 2), "DMs seem to be dispensable elements functioning as sign-posts in the communication facilitating the hearer's interpretation of the utterance on the basis of various contextual clues".

Spoken Arabic of Jordanabounds with various DMs used in daily interaction such as شاء

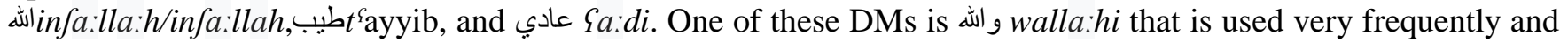
widely in daily speech. Its frequency is a direct result of the influence of Islam that it is a form of oath or swearing used by Muslims in general and Jordanians in particular to express their commitment to what they say and indirectly it indicates that the speaker believes in God. It is one of the popular oath expressions in Jordan among

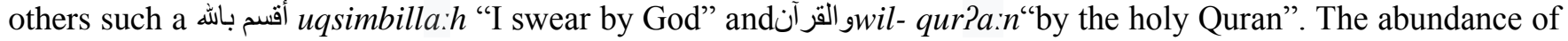
oath in Jordan is a reflection of the influence of Islam on the Arabicculture. The grammatical form of wallahi is a prepositional phrase, consisting of the particle واوwaw"by" known in Arabic grammar as an oath waw (waw alqasam), the proper noun Allah (God) and the case marker of genitivei. Another variant of wallahi is wallah (without the genitive case marker), they are both used interchangeably in Jordanian Arabic context though wallahi is more frequent than wallah. The researcher has observed that Jordanian speakers remarkably employ wallahi to convey a wide variety of functions in different contexts. wallahi whose literal meaning is an oath expression is frequently used in Arabic to serve other functions or mostly it is not used as an oath marker. Hence, it can be claimed that wallahi is a multifunctional DM in Jordanian spoken Arabic. Surveying the literature on Jordanian DMs, the researcher claims that this DM has not yet been dealt with. Therefore, these observations call the researcher to undertake a study to examine and describe the uses and functions of this marker in Jordanian Arabic. The focus of the present paper will be on the DM wallahi that the researcher assumes it serves different functions in different contexts such as surprise, threat, promise, apology, admiration, warning, and blaming. 


\section{Literature Review}

Mughazy (2001) explores the functions of wallahi in the Egyptian Arabic from the perspective of politeness theory of Brown and Lavinson. He argues that the oath phrase wallahi is used interchangeably with other oath expressions such as وwinnabi (by the Prophet), andwilinji:l(by the Bible). The use of these oath expressions is motivated by the religious beliefs of the speaker. He discusses that it has different uses and distributions. The study finds out that non-oath wallahi is used as a discourse particle in Egyptian Arabic to serve two functions. The first one isto function as a politeness marker, preceding potentially face-threating speech acts (e.g. advising, suggestion, and criticizing)and mitigating and reducing undesired effects (e.g. impositions) in spoken conversations. The other one is used as a power marker to determine the (most appropriate) politeness strategies to be employed in a given context. Based on a corpus of real informal interactional conversations and interviews,

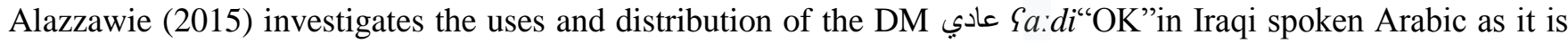
observed to be extensively utilized in the dialect. He finds out that this DM performs a wide variety of pragmatic functions (to indicate the speaker's beliefs, attitudes, and opinions) and discoursal functions (to signal and maintain textual cohesion and organization as well as the flow of conversation). A multiplicity of varied functions and uses in different situations are revealed in the study, for example, to indicate sympathy, support, encouragement, consolation, mitigation, agreement, disagreement, reprimand, sarcasm, and permission. This DM is described to occur initially and finally, syntactically optional, multi-functional expression, and a crucial property of spontaneous spoken discourse.

From a socio-pragmatic perspective in the light of the relevance theoretic framework (Blakemore, 1987), Bidaoui (2015) examines the use of DMs of causality (e.g. li?annu "because")and clarification (e.g. yaSni "I mean") in face-to-face interaction from three Arabic spoken dialects: Egyptian, Moroccan, and Algerian. The results show thatthe realization of these two types of DMs (causality DMs and clarification DMs) is highly influenced by education, nationality, form of interaction, and the speaker's individual choices. As one of the most commonly used expressions among Jordanians, Mehawesh and Jaradat (2015) examine the functions of the religious expression إن شاء اله inshallah"God willing” in daily interactions in spoken Jordanian Arabic, based on Grice's cooperative principle (1975). They discuss that this DM has different pragmatic meanings besides its semantic meaning, serving to indicate contextually irony, threatening, prohibition, wonder, wishing, and a positive reply. It is found that the utterances with this expressions do not offer the same function after the deletion of inshallah, which reflects its crucial role in identifying the intended meaning by the speaker in context. To serve various meanings or functions other than its literal content, the study reveals that this DM, to a large extent, flouts the maxim of quality.

In the spoken Arabic of Arabian Gulf, Abdeljawad and Radwan (2016) explore the role of the DM Inzeen (corresponding to "OK" or"well" in spoken English) in establishing and sustaining global and local conversational coherence. The study identifies a set of functions that this DM serve in the data under consideration, for instance, an agreement marker, a threat marker, a tag marker, topic management marker, and a cohesive marker. Nazzal (2005) investigates the pragmatic functions of the religious expression inshallah used by Muslims in social context. According to the study, inshallah is found out to perform a host of associated functions such as mitigating ones commitment for a future actions, mitigating the undesirable consequences on the hearer, expression indirect rejection, and expressing uncertainty. Farghal (1995) addresses the pragmatics of inshallah in Jordanian Arabic, arguing that its use has shifted from the propositional content to acquire pragmatic meanings in day-to-day interactions. His analysis reveals that this DM demonstrates diverse illocutions (speech act functions) in speech situation, for instance, directive, commissive, and expressive. Drawing on Discourse Analysis and Relevance Theory as a theoretical framework, Al-Harahsheh and Kanakri (2013) deal with the pragmatic functions of the DM "tayyib" (okay) in spoken Arabic variety of Jordan used in dyadic and spontaneous conversations by university students . In their corpus, the DM is observed to offer diverse functions. Among them are agreement, disagreement, objection, permission, topic-shift, and topic-termination. Using a corpus of colloquial movies, Hussein (2016) investigates the syntactic and pragmatic functions of the DM keda in Arabic Egyptianoral discourse within sentence level and above sentence level in order to identify the semantic and pragmatic meanings. Syntactically, it is found that this DM acts like, for example, a subject, an object, and a predicate, an interrogative marker, demonstrative pronoun (this and that), an adverb (manner and location). Pragmatically, it is found to indicate functions such as understanding, blaming, seeking agreement and confirmation, emphasis, and face-saving. Ismail (2015) studies the use of three DMs in a colloquial corpus of 
Egyptian Arabic films, namely, $t^{\uparrow} a b, t^{\uparrow} a y y i b$, and $b a ? a$. He argues that these DMs are found in the corpus under investigation to serve a multitude of functions on discourse coherence, interpersonal and speech acts levels e.g. to mark contrast, conclusion, turn-taking, reluctance, sarcasm, surprise, end of patience, and politeness.

\section{Theoretical Framework}

It is unanimously agreed that DMs are multifunctional and they appear to have a wide spectrum of uses and functions on different levels. Following Fraser (1999: 950) that every DM carries "a core meaning which is procedural, not conceptual, and their more specific interpretation is 'negotiated' by the context", the study assumes that wallahi has a specific, core meaning, namely an oath, even it is observed as will be discussed later that it has a wide set of non-literal meanings, "leaving the burden of interpretation to pragmatics" (Hansen, 2006, p. 26). Therefore, an eclectic analytical method, as a theoretical framework, will be employed to uncover the functions of wallahi in Jordanian spoken Arabic. It comprises generally Discourse Analysis, Pragmatics, and Conversation Analysis and particularly Fraser's Grammatical-Pragmatic Perspective (1999), Searle's Speech Acts Theory 1969 (it includes five types: Representatives, Directives, Commissives, Expressives, and Declaratives), Grice's Cooperative Principle 1975 (it includes four maxims quality, quantity, relevance, and manner), and Brown and Levinson's Politeness Theory (1987).

\section{Methodology}

The main aim of the present study is to investigate the different functions and uses of the DM wallahi in Jordanian spoken Arabic. The reason behind selecting spoken discourse rather than written one is twofold: the DM wallahi, as the focus of the present study, is predominately used in spoken discourse, and while DMs are used in written discourse, they are proved to be most prevalent and a noticeable feature of spoken discourse, particularly, colloquial form (Schiffrin 1987; Brinton 1996; Schourup 1999). As the study is descriptive in nature, it is largely based on corpus methodology that utilizes natural- occurring language data to provide a vivid and actual description of the phenomenon under consideration. To meet the purpose of the study, a corpus of spoken conversational data was compiled by recording native speakers of Jordanian Arabic in everyday situations. It consists of 26 different conversations as they are of varied lengths, in total 8 hours. The duration of conversations varied approximately from 10 minutes to 40 minutes. The process of data collection took around four weeks. The tape-recorded interactions are derived from face-to-face and cell phone conversations as well as chats with some friends, acquaintances, students, and colleagues, which were carried out on various casual occasions. The number of the participants is26, aged from 18-50 and varied in gender, education, and job. The number of male and female participants is equal to avoid any potential gender implication. They all were told in advance that their conversations were being recorded, without informing them of the specific nature of the study for averting any potential impact on the recorded speech but they were requested to talk in natural manner.

\section{Findings and Discussion}

As argued earlier, the present study aims at describing the functions and uses of the DM wallahi in the spoken Arabic of Jordan used in daily communication. This section will present the main findings of the present research. The findings undoubtedly prove that wallahi is multifunctional used to serve a variety of functions. Ten functions served by wallahi have been observed in the corpus under examination: to introduce an acceptance, an apology, a threat, and a compliment, and to serve as a request softener or mitigator, a marker of elaboration, a continuer, a marker of confirmation, a marker of complying with a request, and a filler marker. In this section, each function served by wallahi will be defined and discussed, accompanied with illustrative examples extracted from the conversation data compiled for the purpose of the present study.

\subsection{To introduce an acceptance}

One of the frequent functions of wallahi in the corpus under consideration is to introduce acceptance, especially, in the context of receiving invitation. Used in daily life as a communicative act to maintain good relationships, invitations are intended to address "the invitee's positive face" (Al-Khatib: 2006, p. 272). This holds true in the case of accepting invitation. Pragmatically, acceptance is a commissive speech act that commits its speaker to a proposed future action "whatever his actual intention and even if he later changes his mind" (Tiersma, 1986, p.196).In Example (1) below that occurred between two friends, Speaker A invites the addressee to having a dinner at Ahmed's house tomorrow. Speaker A's intention is made straightforward that the illocutionary force of his utterance is an invitation awaiting an acceptance, particularly, he explicitly expresses his desire to gain a positive response (acceptance) from the invitee with respect to the planned future dinner. 
This invitation is responded with an evident acceptance on the part of Speaker B (the invitee). This acceptance introduced by wallahi is in line with what Strawson (1964) stresses that the speaker should find a way to make his intention clear.

\section{Example (1)}

Speaker A: أحمد عازمنا ع العثا عنده بكره وحابين تكون معنا فشو رايك مايك

(Ahmed invited us to a dinner at his house tomorrow and we would love you to join us. So what do you think?) Speaker B: الهه النا الشرف وربنا يبارك فيك و أكيد راح نحضر بإذن الساله

(It is my pleasure and may Allah bless you. Sure I will come, God willing)

It is noticed that wallahi in Jordanian Arabic is used commonly to introduce most of accepting invitation instances. In the given example, speaker B initiates his acceptance with the use of the DM wallahi, followed by making use of polite, positive expressions of "it is my pleasure", "may Allah bless you", and "sure I will come", which stress and underscore evidently his pleasure and willingness to the invitation. It is worth mentioning that all occurrences of wallahi introducing acceptance are placed in the initial position of its host utterances. Based on the current findings, wallahi is frequently used to introduce acceptance and agreement on invitations, offers, suggestions, and assessment of a prior proposed event as it imparts, to some extent, positive interactional traits of respect, friendliness and support for the addressee, making him feel he is appreciated and liked.

\subsection{To serve As a request softener or mitigator}

Another function of wallahi observed in the present corpus is to serve as a request softener or mitigator. A request requires that the speaker asks the addressee to perform a particular action which is for the benefit of the speaker and at the expense of the addressee. According to Brown and Levinson (1987), requests are deemed as Face Threatening Acts defined as "acts that infringe on the hearer's need to maintain his /her self-esteem and be respected", which highly implies imposition at the expense of the addressee, therefore, the speaker needs to utilize politeness strategies and devices to redress their force. Requests classified as directive by Searle (1979) threaten the addressee's negative face, which is "the need to be independent, to have freedom of actions, and not to be imposed by others" (Arendholz, 2013, p.60). In politeness theory, to deal with the face-threatening acts, the speaker can mitigate the threats toward the addressee's face defined as "public self-image that every member wants to claim for himself" (1987, p. 61), by making use of politeness strategies. To avoid any sense of imposition and face-threatening, one of the politeness strategies used in Jordanian spoken Arabic found in the corpus is the use of wallahi to introduce the request and minimizeits illocutionary force and its imposition on the addressee. To illustrate this, consider the following example:

\section{Example (2)}

واله لو تفتح الثبالك من ور اك خلي هالهوا يفوت : Speaker A

(Would you please open the window behind you to let some fresh air in?)

Speaker B: إبشر إبشر

(With pleasure)

In Example (2), the speaker feels it is hot inside the roomas the window is closed, therefore, he asks the addressee (his colleague) to open it in order to get some fresh air. Not to be taken as a command which threatens the face of the addressee, the speaker employs the DM wallahi as a polite marker to mitigate and indicate that it is a polite request rather than an order. The use of wallahi and the conditional particle glaw "if" makes the utterance less direct and softens and downgrades its illocutionary forceof request. Generally speaking, wallahi has an attenuating function of request and is used as a softener of the propositional content of the utterance to protect the addressee's self-image and avoid any potential conflict between the speaker and the addressee.

\subsection{To introduce an apology}

The corpus reveals that wallahi can be usedto introduce an apology for a previous undesirable action or behavior. Apology occupies an important status in human daily communication as an act of politeness and face-saving. Goffman (1971) defines apologies as remedial acts to prevent a worse possible interpretation of actions, intending to reestablish and maintain social harmony after an offense (real or virtual). Apologies are demanded when some behaviors are thought to violate social norms (Cohen \& Olshtain, 1983). It is argued that the apology speech act occurs normally between participants in which one of them expects or perceives that he deserves an explanation or a compensation because of an offense made by the other (Cohen \&Olshtain1983). 
In such a situation, the participant who needs to apologize has one of the following choices: to apologize, to deny the severity, or to deny the responsibility for the action. Like other societies, apology is necessary in Jordanian society to repair the offence and maintain a good relationship with others.In Example (3), speaker A blames his friend (speaker B) indirectly for ignoring his yesterday's many calls as it is deemed impolite act in Jordanian society. In turn, speaker B acknowledges and apologies to him, explaining the reason that his mother was sick and she had to be taken to hospital. The apology given by speaker A is introduced by the DM wallahi as a polite way to offer apology. Speaker B seems to feel bad about being unable to answer his friend's calls yesterday night though he had to do it on legitimate reasons. However, he offered his apology and justification for not answering speaker A's calls. It is noticed in the data that the apology introduced by wallahi is accompanied with intonation to help the hearer identify the next utterance asa serious apology. As seen in the given example, wallahiis used to introduce and intensifies the apology.

Example (3)

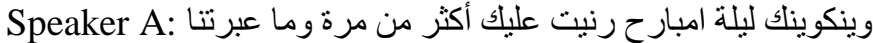

(Where were you yesterday night? I rang you up many times but you ignored me.

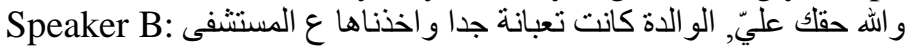

(I'm so sorry. My mother was seriously ill and we had to take her to hospital)

\subsection{To serve as a marker of elaboration}

Wallahi is found in the corpus, though less frequent than other functions, to preface a kind of elaboration to what has been given before, adding more additional information on a state, event, person, entity, concept, topic, etc. described or presented in the prior discourse. To illustrate this, consider the following example:

\section{Example (4)}

Speaker A: هالطالب فعلا مؤدب وشاطر

(The student is very polite and clever)

و والله و ابوه زلمه خلوق وصاحب دين وبلعب بالمصاري لعب : Speaker B

(And his father is a principled, religious, and very wealthy man)

This example occurred between two university doctors talking during their office hour. Speaker A tells speaker B about some positive attributes or qualities of one of their students that he is clever and polite. Speaker B seemsto be more knowledgeable about the student, therefore, to contribute to this subject presented in speaker A's utterance, he elaborates on the student being talked about by giving more additional information about him. He adds further details with respect to the student's father by describing his attributes in a hint that he is influenced and acquired themfrom his father. These additional details are prefaced and initiated by the use of the DM wallahi, which is equivalent in this meaning as elaborative to "and, also, as well" in English.

\subsection{To serve as a continuer}

The results show that wallahi can be used in Jordanian spoken Arabic to serve an interactional function as a continuer that maintains the flow of discourse. According to Schegloff (1982), a continuer is a marker used by conversationalists in an extended unit of speech to indicate that they know that their co-participant's talk is still ongoing and that s/he can continue speaking. It is also facilitative that it encourages or urges the current speaker to continue by marking to him that the addressee's desire for the talk to go on, thus, perceived as a floor-yielding signal (O'Keeffe et al, 2007).

Wallahi as the findings show is found in the corpus to serve as a continuer in conversations to indicate that the addressee is listening, following, and paying attention to what the current speaker is talking about and to indicate that he encourages him to keep the floor. Wallahi as seen in Example (5) is used by speaker B to cede the floor to speaker A, who is apparently engaged in the on-going speech. In this case, speaker B intends by the DM wallahi that he is still listening and following, and paying his attention to what is being said by speaker A. speaker A understands that wallahi used by speaker B is not an interruption of his talk but an interactional and discursive marker that speaker B is eager for more. It is worth mentioning that the use of wallahi as a continuer is observed to occur alone or in isolation in most cases.

Example (5)

Speaker A: بالصدفة امبارح لقيت العميد وسألته عن طلب الترقية وحكالي لسا اللجنة ما ناقشت الطلب (I ran into the dean yesterday at the department and I asked him about my promotion application but he told me the committee hadn't met yet). 


\section{Speaker B: واله}

(Yeah)

Moreover, this function of wallahi is taken as a responsive one corresponding to English yeah, yes, aha, that reflects a positive listenership so as to create and maintain more interactive communication among interlocutors in speech situation. This function which is expressed verbally in the example given above is accompanied or replaced by non-verbal communication or gestures (e.g. head nodding, gazing), these contextual elements help interpret wallahi as a continuer and a sign to the speaker to keep talking.

\subsection{To serve as a marker of confirmation and affirmation marker}

Wallahi is used to convey the discourse function of confirmation and affirmation to a statement or proposition given in prior discourse. This discourse function of wallahi is observed to occur frequently in the corpus under examination (in total 22 occurrences), thus, it is one of the major functions of the DM wallahi in Jordanian spoken discourse. Wallahi as a confirmation and affirmation marker tends to occur at the initial position of the utterance it introduces, though it is observed to occur less frequently in the final utterance position as indicating that the listener is in agreement with the prior speaker's viewpoint or judgment. To illustrate this, consider the following example:

\section{Example (6)}

Speaker A: هالز لمة بصر احة بكذب علينا ومش قادر اصدقه

(This man is lying to us and I can't believe him)

Speaker B: والله معك حق فعلاً

(Sure, you areright)

Speaker A thinks that the man being talked about did not tell the truth (telling lies), which is confirmed and affirmed by speaker B's statement that what speaker A has said about the man is right.The use of expressions such as "فعلا "really" create a sense of strengthening and reinforcing the speaker A's affirmative reaction concerning speaker B's statement, especially to eliminate the speaker A's feeling that his judgment is inaccurate or untrue as it happens that the speaker may think the other speaker or listener could disagree with him. Therefore,these expressions co-occurring with wallahi can be understood as intensifiers and positive emphatic markers.

\subsection{To introduce a threat}

Another function served by wallahi in the corpus is to introduce a threat. Threat means that the speaker will pledge to do unpleasant something in the future in the case the hearer does or doesn't do what the speaker wants it or doesn't. In uttering a threat, the speaker states that he will do something unpleasant (e.g. harm or injury) to the addressee under certain circumstances, the speaker commits himself to a certain action in the future on condition that the addressee does or does not do something the speaker wantshim to do or not to do (Plag et al, 2009).

According to the findings, wallahi is used to introduce the speech act of threating, which is a commissiveact (Searle, 1975) as it assumes a commitment or obligation to do something in the future. To illustrate this function, consider the following example

Example (7)

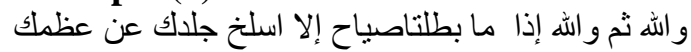

(If you don't stop crying, I'll skin you alive)

As seen in Example (6), the speaker is extremely annoyed with his young son's crying. Therefore, he threatens to beat him hard unless he stops crying. Whether this threat is serious, it is used in such a context to frighten the threatened one so as to make him stop doing something the speaker does not like it. Remarkably, it is noticed that all occurrences of wallahi as introducing a threat are followed by conditional sentences(if clause) as the use of conditional form is one of the major linguistic devices to encode the speech act of threat in Arabic. It is noticed that the repetition of wallahi is only observed in the context of delivering a threat as well.

Sometimes the repetition is to indicate and emphasize that he is serious and committed to do what he is threatening with, which helps make the addressee perform what he is asked to do.

\subsection{To serve as a marker of complying with a request}

According to the findings, wallahi is also found to indicate complying and responding positively and cooperatively to a request for particular information. The request may entail the speaker's right to request and the hearer's obligation to comply with the given request in speech situation. Complying with the request reflects that 
the hearer is cooperative and willing to meet what the speaker needs. In such a context the findings show that the use of wallahi serves to indicate that the addressee is willing and competent to cooperate with the requester. That is, wallahi utilized by the speaker to signal his intention to respond and the request does not threaten his face as an impolite act. The following example illustrates that wallahi is made use of to show the addressee's willingness to comply with his colleague's request.

\section{Example (8)}

Speaker A: اسمع احكيلنا عن اجتماعكم امبار ح بالجامعة (1)

(Listen, tell us about the meeting yesterday at the faculty)

Speaker B: و الله ما صار اشي بس حكينا عن عمل ورشات تدريبية داخل القسم

(Nothing really happened but we talked about holding training workshop sat the department)

As shown in the example, Speaker A asks speaker B to tell him about the meeting. Then, speaker B complies with the request by providing the requester (speaker A)with some sufficient information with respect to the meeting being asked about. The use of wallahi at the beginning of speaker B's reply indicates that he understands that this is a request, thus, he responds by giving speaker A what he wanted to know, which implies that the speaker B accepts to say something concerning the speaker A's utterance. This function of wallahi is a responsive one to meet the expectation of speaker A to get speaker B to carry out the requested act in situation by telling about the subject being asked for. The occurrence of wallahi in the corpus to comply with a request is observed to come in the form of an answer to a question. It is found also that wallahi as a marker of complying with a request occurs only in the initial position, rare cases of final occurrences are found but to signal confirmation rather than complying with request.

\subsection{To serve as filler marker}

Fillers marker are words or phrases used to indicate a pause or hesitation in conversation known also as conversational fillers, pause fillers, and gap-fillers such as "um, ah uh, okay like, and you know" in English. They are very commonly used elements in spoken discourse in all languages. They are used for different functions such as to indicate the speaker needs some time to gather and shape his ideas, is engaged in a cognitive process (thinking or remembering), to hold the turn taking floor while thinking, to bridge interactional silence, to plan for the next discourse, or he is hesitant, uncertain, confused, reserved orupset. They do not encode primary communicative messages by the interlocutors but collateral ones in context. The analysis of the corpus yields that wallahi is employed by Jordanian speakers as a filler marker in their speech, especially, when they stall or pause for a short whileto think of what should be said and should not, formulate their ideas and language, or to remember something related to the talk at hand. Therefore, wallahi is used mainly to fill the speech gap or silence in conversation and simultaneously to keep the floor that the speakeris going to speak immediately. The findings display that wallahi is used to play the role of a filler marker when the addressee is trying to think quickly about what to say next before holding his conversational turn. To illustrate this functions, consider the following example

\section{Example (8)}

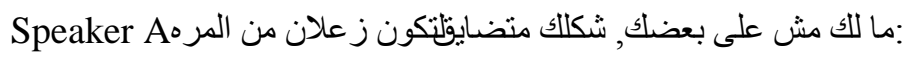

(What is wrong with you? You look upset...Are you angry with your wife?)

Speaker B: والله ما فيه شي محرز بس انته مش غشيم النسو ان دايما عقلهن ازغير

(Nothing important, you know, women are always fools)

Speaker A tries to get speaker B to reveal why he is not himself and looks upset. Speaker A arouses a socially sensitive and personal issue that touches the private life of the addressee as both interlocutors are close friends. However, the addressee does not want to engage in talking about such a matter, therefore, he thinks for a moment of what to reply to what speaker A has noticed.

Consequently, he employs the DMwallahi as a filler, which may leave an impression on the part of the speaker A that this is a sensitive question or improper interference in speaker B's personal life, or to indicate that the addressee is confused, reluctant or unready or unwilling to respond to this abrupt question invoked by speaker A. During this pause by using wallahi, which is sometimes prolonged phonologically, the addressee is thinking of a good answer and reaction that expresses his reservation and at the same time not to embarrass his friend or threaten his social face. The filler wallahi is found in the corpus that its final suffix $i$ is prolonged or stretched 
phonologically(lengthened i) as wallaahiiiiii, which helps signal and mark its filling function. This is the only case in the corpus that the genitive suffix $i$ is prolonged while in other uses of wallahi it is not prolonged.

\subsection{To introduce a compliment}

Compliments are recognized as expressive speech act in which speakers express their positive attitudes toward others (e.g. their behaviors "you are so generous", appearance "your dress looks nice", and possessions "your car is luxurious"). Holmes (1986, p. 485) defines a compliment as attributing explicitly and implicitly "credit to someone...for some 'good' (possession, characteristic, skill, etc.) which is positively valued by the speaker and the hearer". According to present results of the study, the DM wallahi is used to introduce compliments toward others, especially, personal appearance and qualities as illustrated in the following examples given by different speakers.

\section{Example (10)}

و الله انك فنانة طبخ و أكلاك دايماً خر افي و هاظ أحس منسف أكلته بحياتي (10)

(You are a fantastic cook and your cooking is always fabulous. It's the best Mansaf I've ever eaten.

والله إنته ما فيه منأك-B (You

(you are the best)

و الله إنك حشم وما تقصر (Y)

(You are always helpful and cooperative).

D- ماله احلاقتك من الآخر

(Your haircut looks so nice)

The excerpt (A) in Example (10) is uttered in a context that a sister invited her brother and his wife to dinner. He liked the food cooked by his sister for its taste sounded very delicious. Therefore, he expressed his admiration by producing a suitable compliment "you are a fantastic cook".He attributed positive qualities and evaluation to the addressee, his sister. The paralinguistic elements, especially intonation, are very significant and helpful in signaling the truthfulness of the compliments. It is found that all the occurrences of wallahi as introducing compliments are accompanied with an intonation that helps identify that the host utterance of wallahi is a compliment.

\section{Conclusion}

The purpose of the present paper was to investigate and describe the uses of the DM wallahi in spoken Arabic of Jordan from a pragma-discourse perspective, based on a corpus of natural-occurring conversational data. The findings reveal that the DM wallahi is multifunctional, utilized in the corpus under consideration to perform a variety of functions. Ten different functions and uses were accounted for in the study: to introduce an acceptance, to introduce an apology, to introduce a threat, and to introduce a compliment, to serve as a request softener or mitigator, to serve as a marker of elaboration, to serve as a continuer, to serve as a marker of confirmation, to serve as a marker of complying with a request, and to serve as a filler marker. It was also found that wallahi tends to occur initially more than medially and finally. The study recommends that further research on the use of wallahi in wider contexts and with employing larger amount of data can account for more functions and features. Dealing with wallahi in other Arabic spoken dialects such as Arabian Gulf, Syrian, Egyptian, and Iraqi are recommended as well.

\section{References}

Abdeljawad\& Abu Radwan (2016). Conversational Coherence: The Role of Inzeen (Okay) In Arabian GulfSpoken Arabic. International Journal of Arabic linguistics (IJAL), 2(1), 1-18.

Abraham,W. (Ed.) (1991). Discourse Particles in German: How does their illocutive force come about? Amsterdam: John Benjamins.

Aijmer, K. 2002. English discourse particles: evidence from a corpus. Amsterdam: John Benjamins Publishing Company.

Alazzawie, Abdulkhaliq. (2015). Padi as a Discourse Marker in Spoken Iraqi Arabic. Theory and Practice in Language Studies, 5(7), 1352-1360.

Al-Harahsheh, Ahmad \&Kanakri, Mahmoud (2013). The Pragmatic Functions and the Translatability of "Tayib" in Jordanian Spoken Arabic. US-Foreign Language .Vol.11 No.3.pp.196-202.

Al-Khatib, Mahmoud. (2006) The pragmatics of Invitation Making and Acceptance in Jordanian Society. Journal of Language and Linguistics 5-2: 272-294.

Arendholz, Jenny. (2013. (In)Appropriate Online Behavior: A Pragmatic Analysis of Message Board Relations. John benjamnins publishing co. 
Bidaoui, Abdelaadim. 2015. Discourse Markers of clarification and causality in Maghrebi and Egyptian dialects: a sociopragmatic perspective. Ph.D thesis. University of Illinois.

Blakemore, D. L. (1989). Denial and contrast: a Relevance theoretic analysis of 'but'. Linguistics and Philosophy 12. 15-37.

Blakemore, D. (2001). Relevance and linguistic meaning: the semantics and pragmatics of discourse markers. Cambridge: Cambridge University Press.

Brinton, L., J. (1996). Pragmatic Markers in English: Grammaticalization and Discourse Functions. Berlin: Walter de Gruyter.

Brown, Gillian and Yule, George (1983). Discourse Analysis (Cambridge Textbooks in Linguistics). Cambridge: Cambridge University Press.

Brown, P., \& Levinson, S. (1987). Politeness: Some language universals in language use. Cambridge: Cambridge University Press.

Cohen, A. \& Olshtain, E. (1983). Apology: A speech act set. In Wolfson\& E. Judd (Eds.), Sociolinguistics and Language Acquisition (18-35). Rowley, MA: Newbury House.

Farghal, Mohammed. (1995). "The pragmatics of 'inšāllah in Jordanian Arabic. Multilingua - Journal of Cross-Cultural and Interlanguage Communication. Volume 14 no 3. 253-270.

Fraser, B. 1999. What are Discourse Markers?. Journal of Pragmatics. 31: 931-52.

Goffman, Erving (1971). Relations in Public: Microstudies of the Public Order. New York, Harper and Row.

Grice, H. P. (1975). Logic and Conversation. In: Cole, P., Morgan, J.L. (Eds.), Syntax and Semantics, vol.3. New York: Academic Press, pp. 41-58

Hansen, Maj-Britt Mosegaard (2006). "A dynamic polysemy approach to the lexical semantics of discourse markers (with an exemplary analysis of French toujours)". In: Fischer, Kerstin (ed.). Approaches to Discourse Particles. Oxford: Elsevier, pp. 21-41.

Holmes, J. (1986). Compliments and compliment responses in New Zealand English. Anthropological Linguistics, 28(4), 485-508.

Hussein, Mona. (2016). Propositional and non- propositional functions of /Keda/ in the language of Egyptian film. M.A thesis, The American University in Cairo.

Ismail, A. (2015) țabasta'zenana ba'a: A corpus-based study of three discourse markers in Egyptian film language. Unpublished MA thesis. American University in Cairo.

Knott, A. (1993). Using cue phrases to determine a set of rhetorical relations. In O. Rambow, (Eds.) Internationality and Structure in Discourse Relations: Proceedings of the ACL SIGGEN workshoP.

Lee-Goldman, R. (2011). No as a discourse marker. Journal of Pragmatics, 43: 2627-2649.

Levinson, S. (1983). Pragmatics. Cambridge: Cambridge University Press.

Mehawesh,M and Jaradat,A.(2015). Inshallah: Extensive Flouting of Grice's Maxim of Quality. Asian Social Science; Vol. 11, No 4:319-327.

Moore, E. 2007. "Yeah-No: A Discourse Marker in Australian English". Unpublished Honours thesis. The University of Melbourne.

Mughazy, Mustafa. (2003). "Discourse Particles Revisited: The Case of Wallahi in Egyptian Arabic." In Perspectives on Arabic Linguistics XV: Papers from the Fifteenth Annual Symposium on Arabic Linguistics, edited by Dilworth B. Parkinson and Samira Farwaneh, 3-18. Amsterdam: John Benjamins Publishing Company.

Nasir, Syarif. (2017). The interpretation of discourse markers ya 'yes' and nggak 'no' in Indonesian. Unpublished M.A thesis. Radboud University Nijmegen.

Nazzal, A. (2005). The Pragmatic Functions of the Recitation of Qur'anic Verses by Muslims in Their Oral Genre: The Case of Insha'Allah, 'God's Willing'. Pragmatics, 15(2/3), 251- 273.

Plag, Ingo, Maria Braun, Sabine Lappe, Mareile Schramm. (2009). Introduction to English Linguistics. Mouton de Gruyter. University of Siegen, Germany.

O'Keeffe,Anne, Michael McCarthy, Ronald Carter. (2007). from Corpus to Classroom: Language Use and Language Teaching. Cambridge press.

Redeker, G. (1990). Ideational and pragmatic markers of discourse structure. Journal of Pragmatics, 14 (3): 367-381.

Schegloff E A. (1982). Discourse as an interactional achievement: Some uses of 'uh huh' and other things that come between sentences. In: Tannen D (ed.) Analyzing Discourse: Text and Talk. Georgetown University Roundtable on Languages and Linguistics 1981. Georgetown University Press, Washington, DC, pp. 71-93

Schiffrin, D. (1987). Discourse Markers. Cambridge: Cambridge University.

Schourup, L. (1999). Discourse markers: tutorial overview. Lingua 107: 227-265.

Searle, John. (1969). Speech Acts: An Essay in the Philosophy of Language. New York: Cambridge University Press.

Strawson, P. F. (1964). Intention and convention in speech acts. Philosophical Review, 73, 439-460.

Tiersma, Peter. (1986). The Language of Offer and Acceptance: Speech Acts and the Question of Intent. 74 California Law Review 189.

Yule, George. (2008). Pragmatic. Oxford university press. 